ZOOLOGIA 29 (6): 540-548, December, 2012

Available online at www.scielo.br/zool

\title{
Genetic profile and molecular resistance of Aedes (Stegomyia) aegypti (Diptera: Culicidae) in Foz do Iguaçu (Brazil), at the border with Argentina and Paraguay
}

\author{
Ana C. Dalla Bona ${ }^{1}$, Carla F. Piccoli ${ }^{1}$, André de S. Leandro ${ }^{2}$, Rosinei Kafka², \\ Adriana L. Twerdochilib ${ }^{1} \&$ Mário A. Navarro-Silva ${ }^{1,3}$
}

\author{
${ }^{1}$ Laboratório de Entomologia Médica e Veterinária, Universidade Federal do Paraná, Setor de Ciências Biológicas, \\ Departamento de Zoologia. Caixa Postal 19020, 81531-980 Curitiba, Paraná, Brazil. \\ ${ }^{2}$ Centro de Controle de Zoonoses. Avenida Maceió, Jardim Ipê, 85869-657 Foz do Iguaçu, Paraná, Brasil. \\ ${ }^{3}$ Corresponding author. E-mail: mnavarro@ufpr.br
}

\begin{abstract}
The genetic variability of populations of Aedes (Stegomyia) aegypti (Linnaeus, 1762) is often low due to the intense selection pressure caused by chemical control measures. In this study, we evaluated the susceptibility of larvae and adults of this mosquito to chemical insecticides, the frequency of the Val1016lle mutation, and the genetic variability of the mitochondrial ND4 gene fragment in the urban area of Foz do Iguaçu, Paraná. The populations of $A$. aegypti in the southern and central regions of the city were resistant to the diagnostic dose of temephos $0.0162 \mathrm{ppm}$. Additionally, we detected difference in susceptibility in the northern population. The resistance ratios (RR95) were 3.8, 4.1, and 4.6 for the populations in the north, central, and south of the city, respectively. The entire population of $A$. aegypti in Foz do Iguaçu is resistant to pyrethroids. The mortality rates are as follows: $72.2 \%$ for cypermethrin (CD: $146 \mathrm{mg}$ i.a. $/ \mathrm{m}^{2}$ ) and $57 \%$ for deltamethrin (CD: $18 \mathrm{mg} \mathrm{i.a.} / \mathrm{m}^{2}$ ). These results corroborate the hypothesis that the mutated $1016 \mathrm{lle}$ allele is present in all analyzed strata. Out of the 234 samples genotyped for the Val1016lle mutation, $15 \%$ were homozygous dominant for the wild allele ( $\mathrm{Val} / \mathrm{Val}), 62 \%$ were heterozygous ( $\mathrm{Va} / \mathrm{lle}$ ) and $23 \%$ were homozygous for the recessive mutation (lle/lle). With respect to the genetic variability of the mitochondrial ND4 gene fragment, $93 \%$ of the sequences analyzed belonged to haplotype 1 , and $7 \%$ belonged to haplotype 2 . The genetic diversity was low, the fixation index was not significant, and gene flow was high. The control of $A$. aegypti in Foz do Iguaçu using temephos and pyrethroids may be compromised because of the reduced vector susceptibility. Populations of $A$. aegypti, that undergoes a sudden reduction in effective population size and become resistant to pyrethroids may differ from the original population in vector capacity.
\end{abstract}

KEY WORDS. Knockdown resistance; mitochondrial DNA; pyrethroids; temephos.

Mosquito control is still the only effective means to protect human populations from the Dengue virus, despite recent efforts to find a vaccine against the disease (Taull 2001). Attempts to control the vector Aedes (Stegomyia) aegypti (Linnaeus, 1762), usually involve a combination of chemical insecticides and environmental sanitation. Unfortunately, however, few insecticides are available for this purpose and because mosquito populations tend to become resistant to them, it is necessary to assess and continually monitor these populations to ensure the success of vector control programs.

In Brazil, two classes of insecticides - organophosphates (since 1967) and pyrethroids (since 1999) - have been used (BRAGA et al. 2004) in the control of A. aegypti. The first cases of resistance to temephos, an organophosphate, were recorded by Maconis et al. (1995) in populations of A. aegypti, in Goiânia and Marilia. After that, a few other studies documented larval resistance to the same compound in several Brazilian populations
(Lima et al. 2003, 2011, MACoris et al. 2003). In countries that share borders with southern states of Brazil, resistant populations have been documented only in Argentina (SECCACINI et al. 2008, LuINÁs et al. 2010). In Paraguay, no research to date was conducted on mosquito resistance to temethos, and mosquito control is limited to areas where A. aegypti is endemic (GÜRTLER et al. 2009).

Cases of resistance to pyrethroids were first detected in 2001 in some populations of A. aegypti in the states of Alagoas, Sergipe, and Rio de Janeiro (Pereira-DA-Cunha et al. 2005). The assessment of vector susceptibility to this class of insecticides involves an evaluation of the biological response of adults using biological assays. Molecular assays are also used for that purpose, as mutations related to pyrethroid resistance occur at the voltage-gated sodium channel, the target site of the insecticide, which keeps the sodium channels of the axon membrane open, stimulating the nerve cells to produce repetitive signals, and resulting in the death of the insect (Braga \& Valle 2007a). A single 
amino acid substitution in this channel causing a reduction in the binding of the pesticide to the voltage-gated sodium channel may be associated with a resistance known as the knockdown resistance (kdr) (KAWADA et al. 2009, García et al. 2009).

Mutations in the voltage-gated sodium channel have been detected in several insects, including $A$. aegypti, that might be associated with resistance (SODERLund \& KNIPPLe 2003). A substitution of adenine for guanine in the codon Val1016 substitutes the amino acid Valine with Isoleucine (Val1016Ile). This substitution is associated with a change in resistance to pyrethroids (SAavedra-Rodriguez et al. 2007, Martins et al. 2009). The allele associated with knockdown resistance is recessive and therefore is only expressed in homozygous individuals (DAvIES et al. 2008). This means that, under intense selection pressure, resistant alleles are selected quickly, changing the genetic structure of the population.

Studying the genetic structure of populations is crucial to understanding the population dynamics of $A$. aegypti (Hiragi et al. 2009). The genetic variability in natural populations of this mosquito has been investigated using molecular markers such as RAPD (Random Amplified Polymorphic DNA) (Julio et al. 2009), microsatellites (PAUPY et al. 2010), SNPs (single nucleotide polymorphism) (Hemme et al. 2010), and mitochondrial DNA (Gorrochotegui-Escalante et al. 2002).

Combining studies on the genetic variability of populations under selection pressure caused by insecticides is important, especially in areas prone to the input of new strains of $A$. aegypti. One such example is the city of Foz do Iguaçu, which shares borders with two Latin American countries and where there is intense trade and movement of people and products. Consequently, the present study evaluated the susceptibility of larvae and adults to chemical insecticides, the frequency of the mutation Val1016IIe associated with resistance to pyrethroids, and the genetic variability of the mitochondrial ND4 gene fragment in populations of $A$. aegypti in the urban area Foz do Iguaçu, Paraná.

\section{MATERIAL AND METHODS}

\section{Capture of $A$. aegypti for the temephos assays, Val1016lle mutation and genetic diversity}

Specimens were collected in the city of Foz do Iguaçu (2532'52"S, 54³5'17"W) state of Paraná, Brazil. Foz do Iguaçu is located in the westernmost portion of the state and borders Puerto Iguazú, in Argentina, and Ciudad del Este, in Paraguay (IBge 2011), with an estimated population of 325,137 inhabitants and an area of $617.70 \mathrm{~km}^{2}$. Foz do Iguaçu is a large city, with over 8,100 buildings. According to the LIRAa (Rapid Survey Index infestation by $A$. aegypti), it is necessary to divide the city area into strata, which are geographical regions with an equivalent number of buildings: each stratum having a minimum of 8,100 and a maximum of 12,000 buildings (MINISTÉRIO DA SAÚde 2005) (Fig. 1).
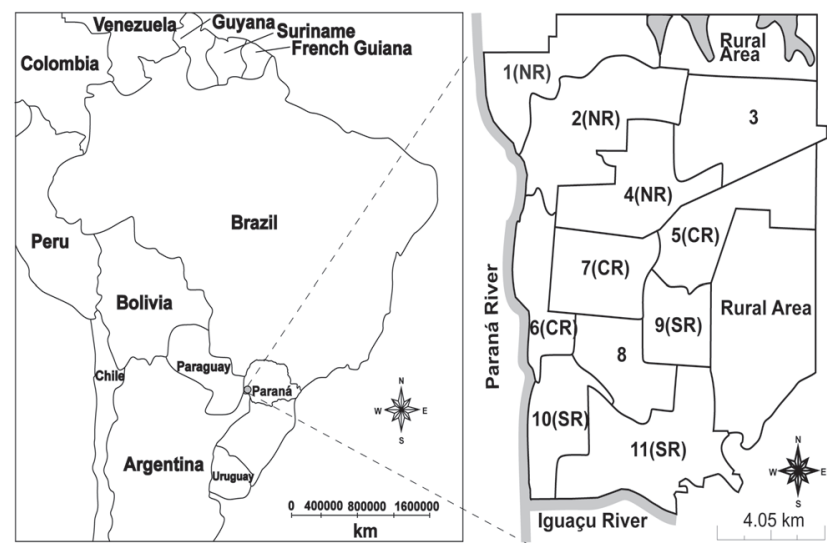

Figure 1. Map of South America with emphasis on the state of Paraná located in southern Brazil. The study area was the city of Foz do Iguaçu, located at the extreme West of the state of Paraná, divided into 11 strata according to number of buildings. (NR) northern region, strata 1, 2 and $4 ;(C R)$ central region, strata 5, 6 and $7 ;(\mathrm{SR})$ southern region, strata 9,10 and 11 .

The samples were collected by the staff members of the Center for Zoonosis Control of Foz do Iguaçu (CCZ) using ovitraps (FAY \& EliASON 1966) in December 2008, February 2009, May 2009 and October 2009. According to LIRAa, in large municipalities it becomes necessary to divide the sampling into two stages: blocks and buildings. Blocks (primary sampling units) and the buildings (secondary sampling units) in each block are randomly selected (secondary sampling units) (MINISTÉRIO DA SAÚdE 2005). For logistical reasons, we chose to use the same number of ovitraps in each stratum $(n=15)$, totaling 165 traps per period. Ovitraps remained in peridomicile for five days, after which they were removed and taken to the laboratory. There, the blades containing eggs of $A$. aegypti were kept in an insectary under controlled temperature $\left(25 \pm 1^{\circ} \mathrm{C}\right)$, humidity $(80 \pm 10 \%)$ and photoperiod (12:12) until the adults emerged.

We used individuals of the F1 generation from the December 2008 sampling for the temephos bioassays. Strata one, two and four, in the northern region of the city, were combined; in the central region, strata five, six and seven; and in the southern region, strata nine, ten, and eleven (Fig. 1). Strata three and eight were excluded from the analysis on temephos susceptibility due to the absence of eggs for bioassays.

In analyzes of the Val1016Il mutation and the fragment of the mitochondrial gene ND4, newly emerged $A$. aegypti individuals were sampled in each of the eleven strata and the four collection periods. The mosquitoes were placed individually in absolute ethanol and stored at $-20^{\circ} \mathrm{C}$.

\section{Capture of A. aegypti for tests with pyrethroids}

The mosquitoes were collected with ovitraps as part of the National Resistance Monitoring programming of $A$. aegypti (MoReNAa) (Braga \& Valle 2007b) in Foz do Iguaçu, from No- 
vember 24 to December 12, 2008. The eggs, collected with ovitraps (FAY \& ELIASON 1966), were used to rear laboratory colonies.

\section{Biological assays}

We performed tests using the insecticide Temephos pestanal $250 \mathrm{mg}$ 97.5\% (Sigma-Aldrich). The calibration and control of the bioassays were performed on the susceptible strain of A. aegypti Rockefeller strain (Centers of Diseasse Control, CDC). Bioassays were performed with a diagnostic concentration of $0.0162 \mathrm{ppm}$ of temephos, which corresponded to twice the lethal concentration, 99\% (LC99), for this susceptible strain. The tests were read after 24 hours, and an estimated larval mortality rate was calculated. Populations with mortality rates above $98 \%$ were considered susceptible, between $80 \%$ and $98 \%$, with alterations in susceptibility, and below $80 \%$, resistant (WHO 1998). Bioassays with multiple concentrations were performed according to the World Health Organization to detect and quantify resistance (WHo 1981a).

In each experiment, nine concentrations were tested, in four replicates. Each concentration had 20 larvae, late third instar, and fourth instar of $A$. aegypti, totaling 720 larvae per experiment. We added $80 \mathrm{ml}$ of purified water and $20 \mathrm{ml}$ of water containing the larvae in all glasses. As population controls, four replicates using ethanol as a solvent were tested.

According Mazzari \& Georghiou (1995), the levels of resistance are defined as: resistance ratio $(\mathrm{RR})<5$, low; between 5 and 10, medium; above 10, high. The lethal concentrations were calculated in the basic program Probit (Finney 1971). The resistance ratios 50 and 95 were calculated by dividing the lethal concentration of the population examined by the lethal concentration of the Rockefeller population.

Bioassays with pyrethroids were performed at the Center for Drug Evaluation and Research Office of the Regional Superintendent of Marilia Endemic Disease Control (SUCEN, Marilia, São Paulo). Qualitative essays, using the diagnostic concentration (DC) on each trial, and paper impregnated with cypermethrin (DC: $146 \mathrm{mg} \mathrm{ia} / \mathrm{m}^{2}$ ) and deltamethrin (DC: $18 \mathrm{mg} \mathrm{ia} / \mathrm{m}^{2}$ ), followed the standard methodology of the World Health Organization (WHо 1981b, c, 1992, 1998). The susceptible Rockefeller strain was used for comparison. The diagnostic concentration was measured after 24 hours, and the rate of adult mortality was calculated. Populations with a mortality rate above $98 \%$ were considered susceptible; between $80 \%$ and $98 \%$, with changes in susceptibility, below 80\%, resistant (Wно 1998).

\section{DNA extraction}

Each specimen was macerated in a microtube using a plastic pestle, followed by the addition of $160 \mu \mathrm{L}$ of lysis buffer (TrisHCl $0.5 \mathrm{M}, 4 \mathrm{M} \mathrm{NaCl}, 0.5 \mathrm{M}$ EDTA) and $20 \mu \mathrm{L}$ sodium dodecyl sulfate $10 \%$. The tubes were incubated in serum bath for 30 minutes at $60^{\circ} \mathrm{C}$. For deproteinization, $50 \mu \mathrm{L}$ of chloroform: isoamyl alcohol $(24: 1)$ were added to each tube. The mixture was centrifuged for 15 minutes at $13,000 \mathrm{rpm}$ in a refrigerated centrifuge at $15^{\circ} \mathrm{C}$. The supernatant was transferred to a fresh $1.5 \mathrm{ml}$ tube, to which $80 \mu \mathrm{L}$ of ammonium acetate (7.5 M) and $300 \mu 196 \%$ ethanol were added. The samples were homogenized by inversion and taken to a $-20^{\circ} \mathrm{C}$ freezer for 30 minutes to precipitate the DNA. Samples were then centrifuged at $13,000 \mathrm{rpm}$ for 15 minutes at $15^{\circ} \mathrm{C}$. After centrifugation, the supernatant was discarded and $300 \mu \mathrm{L}$ of $70 \%$ ethanol were added to the mixture to wash the DNA. The samples were centrifuged again at $13,000 \mathrm{rpm}$ for five minutes at $15^{\circ} \mathrm{C}$. The supernatant was discarded again. The tubes were then placed in an oven at $37^{\circ} \mathrm{C}$ to dry the samples. The DNA was re-suspended in $30 \mu \mathrm{L}$ of TE ( $0.5 \mathrm{M}$ TrisHCl, $0.05 \mathrm{M}$ EDTA and MilliQ water) and stored at $-20^{\circ} \mathrm{C}$. DNA quantification was performed with a NanoDrop ${ }^{\mathrm{TM}}$ spectrophotometer

\section{Voltage-gated sodium channel gene fragment - Genotyping 1016 site}

In order to evaluate the presence of the mutation for pyrethroid resistance, three primers, one specific for the wild allele (5'-GCG GGC AGG GCG GCG GGG GCG GGG CCA CAA ATT GTT TCC CAC CCG CAC CGG-3'), one specific for the mutant allele (5'-GCG GGC ACA AAT TGT TTC CCA CCC GCA CTG A-3') and a third initiator, common to both (5'-GGA TGA ACC GAA ATT GGA CAA AAG C-3') (SAAVEDra-Rodriguez et al. 2007, Martins et al. 2009) were used.

PCR reactions were conducted in a final volume of $25 \mu \mathrm{l}$, and contained $2.5 \mu$ l of $10 \mathrm{x}$ buffer (100 mM Tris- $\mathrm{HCl} \mathrm{pH} 8.3$, $500 \mathrm{mM} \mathrm{KCl}, 15 \mathrm{mM} \mathrm{MgCl} 2), 12.5 \mathrm{pMol}$ of each primer, dNTP $200 \mu \mathrm{M}$ (Amresco, Solon, OH), $100 \mathrm{ng}$ of DNA, 1U of Taq DNA polymerase (Sigma-Aldrich) and MilliQ water. The amplification reactions were performed according to SAAVEDRA RODRIGUEZ et al. (2007). The amplified alleles were checked in $9 \%$ polyacrylamide gel. Seventy-eight and $98 \mathrm{bp}$ bands correspond to the mutant (1016Ile) and wild alleles (1016Val), respectively.

The statistical analysis was performed using the program Bioestat 5.0 (Ayres et al. 2007), using a criterion analysis of variance and Tukey's test, with significance level of 0.05 . The pairwise comparisons of the proportions of heterozygous and homozygous recessive genotypes followed ZAR (2010). Allele and genotype frequencies were calculated according to SALMAN (2007). The allele frequencies remained constant across generations, according to the Hardy-Weinberg model (HARTHL 2008).

\section{Variability in the ND4 mitochondrial gene}

The amplification of the gene segment expressing the subunit 4 of the mitochondrial enzyme NADH dehydrogenase was performed using $20 \mathrm{ng}$ DNA, 12.5 pmoles of each primer (IDT, Coralville, IA, USA), dNTP $200 \mu \mathrm{M}$ (Amresco, Solon, OH), $2.5 \mu \mathrm{l}$ Buffer 10X (100 mM Tris-HCl pH 8.3, $500 \mathrm{mM} \mathrm{KCl,} 15 \mathrm{mM}$ $\mathrm{MgCl} 2), 1 \mathrm{U}$ Taq DNA polymerase (Sigma-Aldrich) and Milli-Q water to a final volume of $25 \mu$ l. The primers used in the amplification and the amplification reactions followed CosTA DA SILVA et al. (2005). The success of the amplification was ascertained using $1 \%$ agarose gel. The reaction was performed using the Qiaquik 
PCR purification kit (Qiagen) according to the manufacturer's instructions. The samples were sent to Center for Human Genome Studies (University of São Paulo) for sequencing using the equipment ABI 3730 DNA Analyzer (Applied Biosystems).

Consensus sequences were obtained using the Staden Package version 1.5. Sequences were aligned using BioEdit version 7.0.0 (Hall 2004) and ClustalW (Thompson et al. 1994). The sequences obtained were compared with sequences available on GenBank, using the tblastx tool for confirmation of the amplified fragment. Genetic diversity and neutrality tests were calculated using the program DnaSP, version 5 (Librado \& RozAs 2009). Analysis of molecular variance (AMOVA) was performed using the program Arlequin version 3.5 (Excoffier \& LISCHER 2010). The number of migrants per generation $(\mathrm{Nm})$ was obtained using the formula $F s t=1 / 2+1 \mathrm{Nm}$ ( $F s t=$ fixation index), considering haploid organisms. Geographical distances were obtained using Google Earth 6.

\section{RESULTS}

\section{Biological assays}

The populations of $A$. aegypti in the central (71\% mortality) and southern (77\% mortality) regions of Foz do Iguaçu were resistant to temephos. In addition, we detected a shift in the susceptibility levels of the northern population (85\% mortality) to the organophosphate at the diagnostic concentration of $0.0162 \mathrm{ppm}$. The resistance ratios of the populations in the northern, central and southern regions were 3.79, 4.06 and 4.65 respectively (Tab. I).

In 2008, the population of $A$. aegypti in the urban area of Foz do Iguaçu was considered resistant to pyrethroids, with a $72.2 \%$ mortality for cypermethrin (LC: $146 \mathrm{mg}$ i.a. $/ \mathrm{m}^{2}$ ) and $57.0 \%$ for deltamethrin (LC: $18 \mathrm{mg}$ i.a. $/ \mathrm{m}^{2}$ ).

\section{Voltage-gated sodium channel gene fragment - Genotyping 1016 site}

A total of 234 specimens were surveyed for the Val1016I1 mutation. Of these, $15 \%$ (35) were homozygous dominant; $62 \%$ (146) were heterozygous and 23\% (53) were homozygous recessive. The genotype frequency of the Val/Ile was higher than that of Val/Val and Ile/Ile ( $\mathrm{p}=0.0002, \mathrm{~F}=12.7356, \mathrm{DF}=2)$. The frequencies of the genotypes bearing the recessive allele were not distributed randomly among the strata. (Val/Ile: $\chi^{2}=28.54$, Ile/Ile: $\chi^{2}=28.16$, critical value 18.30 for ten degrees of freedom). Nonetheless, the population is in Hardy-Weimberg equilibrium (Tab. II).

Table II. Number of individuals analyzed and genotypic frequencies for the mutation on the 1016 codon of the gene fragment of the sodium channel of Aedes aegypti, collected in 11 strata in the urban area of Foz do Iguaçu from Dec 2008 to Oct 2009.

\begin{tabular}{rcccc}
\hline \multirow{2}{*}{ Strata } & \multicolumn{3}{c}{ Genotype frequency } & \multirow{2}{*}{ Total } \\
\cline { 2 - 4 } & Val/Val & Val/lle & lle/lle & \\
\hline 1 & 0.13 & 0.47 & 0.40 & 15 \\
2 & 0.14 & 0.79 & 0.07 & 29 \\
3 & 0.17 & 0.28 & 0.55 & 18 \\
4 & 0.05 & 0.80 & 0.15 & 20 \\
5 & 0.11 & 0.72 & 0.17 & 18 \\
6 & 0.12 & 0.59 & 0.29 & 17 \\
7 & 0.05 & 0.58 & 0.37 & 19 \\
8 & 0.00 & 0.65 & 0.35 & 20 \\
9 & 0.43 & 0.50 & 0.07 & 14 \\
10 & 0.03 & 0.80 & 0.17 & 36 \\
11 & 0.46 & 0.43 & 0.11 & 28 \\
\hline
\end{tabular}

The total frequencies of the Val and Ile alleles were 0.46 and 0.54 , respectively. There were no significant differences in the frequencies of the 1016Val and 1016Ile alleles $(\mathrm{p}=0.109, \mathrm{~F}$ $=2.757, \mathrm{DF}=1)$ in the 11 strata analyzed within the municipality. The mutant allele was more frequent in all strata, except for regions 2, 9 and 11 (Fig. 2).

\section{Variability in the ND4 mitochondrial gene}

The amplified fragment of the ND4 gene was $291 \mathrm{bp}$ long. We observed 10 polymorphic sites and 281 monomorphic sites. The analysis of the amplified fragment of 157 individuals showed that there are two haplotypes in the population of Foz do Iguaçu, 93\% of the H1 [GenBank: JN190355] and 7\% of the H2 [GenBank: JN190356] (Tab. III). The haplotypes can be dis-

Table I. Generation (G), Chi-square, slope, lethal concentrations, resistance ratios to temephos by the larvae of Aedes aegypti in three urban areas of Foz do Iguaçu in 2008, using the cepa Rockefeller as a control.

\begin{tabular}{|c|c|c|c|c|c|c|c|c|}
\hline & G & $x^{2}$ & Slope & LC50 (95\% IC) & LCL95 & LC99 & RR50 & RR95 \\
\hline Rockefeller & Fn & 7.3735 & $\begin{array}{c}6.1402 \\
( \pm 0,2505)\end{array}$ & $\begin{array}{c}0.0034 \\
(0.0033<\mathrm{CL}<0.0035)\end{array}$ & $\begin{array}{c}0.0063 \\
(0.0063<\mathrm{CL}<0.0067)\end{array}$ & $\begin{array}{c}0.0081 \\
(0.0076<\mathrm{CL}<0.0088)\end{array}$ & $x$ & $x$ \\
\hline North & F1 & 5.1269 & $\begin{array}{c}3.7114 \\
( \pm 0,2140)\end{array}$ & $\begin{array}{c}0.0086 \\
(0.0080<\mathrm{CL}<0.0091)\end{array}$ & $\begin{array}{c}0.0239 \\
(0.0221<\mathrm{CL}<0.0262)\end{array}$ & $\begin{array}{c}0.0364 \\
(0.0325<C L<0.0419)\end{array}$ & 2.5294 & 3.7937 \\
\hline Central & F1 & 8.6976 & $\begin{array}{c}4.9158 \\
( \pm 0,2386)\end{array}$ & $\begin{array}{c}0,0118 \\
(0.0113<C L<0.0123)\end{array}$ & $\begin{array}{c}0.0256 \\
(0.0241<C L<0.0274)\end{array}$ & $\begin{array}{c}0.0352 \\
(0.0324<C L<0.0388)\end{array}$ & 3.4706 & 4.0635 \\
\hline South & F1 & 1.9744 & $\begin{array}{c}3.6267 \\
( \pm 0,1533)\end{array}$ & $\begin{array}{c}0.0103 \\
(0.0098<C L<0.0108)\end{array}$ & $\begin{array}{c}0.0293 \\
(0.0271<C L<0.0320)\end{array}$ & $\begin{array}{c}0.0451 \\
(0.0406<C L<0.0511)\end{array}$ & 3.0294 & 4.6508 \\
\hline
\end{tabular}




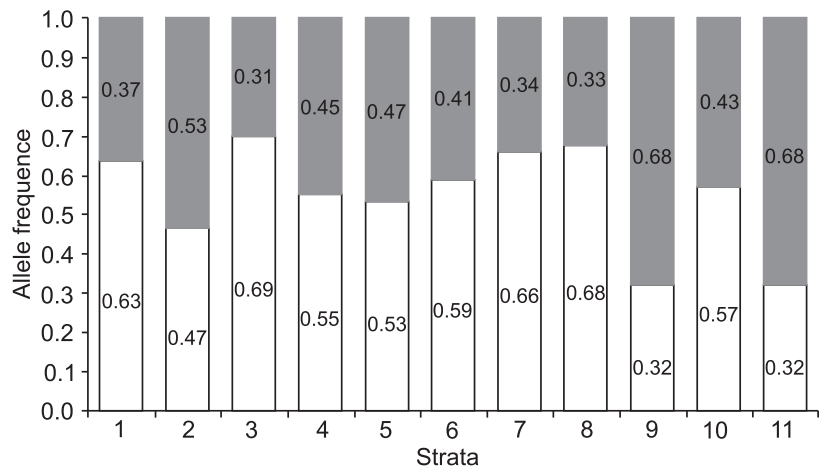

Figure 2. Frequencies of the wild (1016Val, gray bars) and mutante (1016lle, white bars) alleles for the mutation on the 1016 do fragmento codon of the voltage-gated sodium gene of Aedes aegypti in 11 strata of the urban area of Foz do Iguaçu.

Table III. Number of individuals of each haplotype of Aedes aegypti, collected from 11 strata at the urban area of Foz do Iguaçu, from December 2008 to October 2009.

\begin{tabular}{crrrrrrrrrrrr}
\hline \multirow{2}{*}{ Haplotype } & \multicolumn{11}{c}{ Strata } & \multicolumn{11}{c}{ Total } \\
\cline { 2 - 12 }$y$ & 1 & 2 & 3 & 4 & 5 & 6 & 7 & 8 & 9 & 10 & 11 & \\
\hline $\mathrm{H} 1$ & 10 & 10 & 18 & 16 & 10 & 18 & 16 & 10 & 10 & 18 & 10 & 146 \\
$\mathrm{H} 2$ & 0 & 0 & 2 & 4 & 0 & 1 & 2 & 0 & 0 & 2 & 0 & 11 \\
\hline
\end{tabular}

tinguished by ten transitions: $\mathrm{G} \leftrightarrow \mathrm{A}$ (sites 039, 219), $\mathrm{T} \leftrightarrow \mathrm{C}$ (sites 069, 084, 201); A $\leftrightarrow \mathrm{G}$ (sites 117, 162, 210, 219), C $\leftrightarrow \mathrm{T}$ (site 240), and one transversion: $\mathrm{A} \leftrightarrow \mathrm{T}$ (site 081).

The haplotype diversity in our data was $0.131( \pm 0.035)$, nucleotide diversity was $0.00475( \pm 0.00127)$ and the average number of nucleotide differences was 1.311. The results of the tests for neutral selectivity were not significant, according to the neutral evolution hypothesis test (KIMURA 1968) ( $\mathrm{p}>0.05$; Tajima D Test: -0.62896; D Test of Fu and Li: 1.34621; F Test of Fu and Li: 0.76017; Fu Fs Test: 6470).

Heteroplasmy, the presence of more than one mitochondrial DNA in the same individual, was found in four analyzed individuals, at the polymorphic sites described in this study (sites 069, 084, 117, 162, 201).

For the analysis of molecular variance, the populations were grouped according to their strata. The results show that almost all the variation $(99.78 \%$ ) was found within populations, whereas $0.22 \%$ of the variation occurred among populations, with a value of $F s t=0.00217$, not significant $(\mathrm{p}=0.4164)$. The gene flow $(\mathrm{Nm})$ for the total population was 230. In pairwise comparisons among the strata, all values of $F s t$ were not significant.

\section{Correlation between genetic diversity and KDR resistance}

Seventy-nine individuals were analyzed concurrently for the ND4 fragment and the 1016Ile mutation, 73 individuals with haplotype H1 and six with haplotype H2. Both 1016Val and 1016Ile alleles were observed among individuals with haplotypes $\mathrm{H} 1$ and $\mathrm{H} 2$ (Figs 3-6).

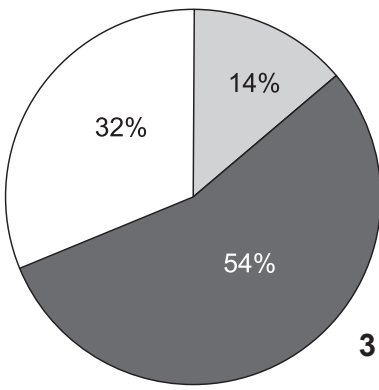

$\square \mathrm{Val} / \mathrm{Val}$

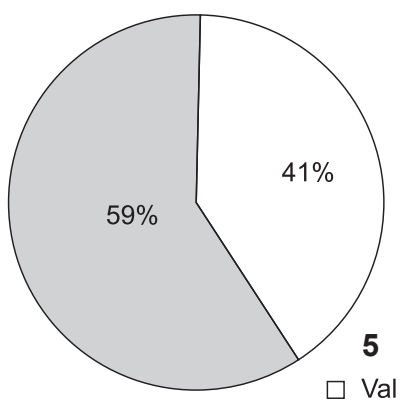

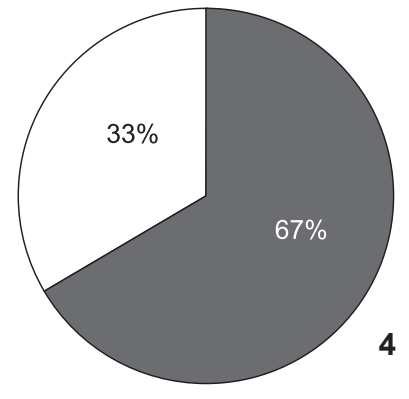

Val/lle $\square$ lle/lle
Figures 3-6. Percentage of homozigous recessive, dominant and heterozigous with respect to the haplotypes $\mathrm{H} 1$ (3); $\mathrm{H} 2$ (4) of Aedes aegypti. Percentage of recessive and dominant alleles with respect to haplotypes $\mathrm{H} 1$ (5); $\mathrm{H} 2$ (6) of Aedes aegypti.

\section{DISCUSSION}

Foz do Iguaçu is known for its tourist attractions and as an important commercial activities, yet the region had many cases of dengue in recent years (DUQUE et al. 2010). In this area, chemical insecticides are used to control the dengue vector, leading to the selection for insecticide resistance in these insects. Larval resistance to temephos in Foz do Iguaçu was reported by Prophiro et al. (2011) in 2006/2007. Their study divided the city into a northern and a southern region. The mortality ratio (CD: 0.0060) for $A$. aegypti in the southern region (RR95: 3.62), was $77.5 \%$, and $75.9 \%$ in the northern region (RR95: 3.13). According Mazzari \& Georghiou (1995), resistance levels below five are considered low. However, when temephos use is interrupted in locations where the resistance ratio is high (greater than 10), resistance decreases only gradually, delaying the possibility of efficient use of temephos for several years (Montella et al. 2007). In 2006, at the technical meeting of the National Resistance Monitoring of $A$. aegypti (MoReNAa), it was determined that vector control programs in municipalities with resistance ratio 
of $A$. aegypti greater than three should use another insecticide with a different mechanism of action, in order to reduce the selection pressure of temephos on the exposed populations (Ministério da SaÚde 2006). For instance, in 2011, the local vector control service in Foz do Iguaçu began to use the larvicide diflubenzuron, which interferes with the synthesis of chitin. In addition to the use of alternative insecticides, populations should continue to be monitored with respect to their resistance to temephos until this insecticide can be used again. Moreover, cultural changes need to take place in the community in order to effectively control A. aegypti. For instance, people should avoid disposing of containers that accumulate water and serve as oviposition sites (Guirado \& Bicuso 2009).

Our bioassays detected resistance to pyrethroids in adult populations of $A$. aegypti in the urban area of Foz do Iguaçu. This was further confirmed after analyzing the frequency of the mutation in the gene fragment of the voltage-gated sodium channel, with the 1016Ile allele being found at high densities in the analyzed specimens in all strata. Heterozygotes were present in all but three strata in the urban area. Despite the selective advantage of heterozygous genotypes, mating between heterozygous individuals results in $25 \%$ of the progeny carrying the recessive mutation 1016Ile (SALMAN 2007).

Previous preliminary analysis of the population of $A$. aegypti in Foz do Iguaçu in hot spot areas with respect to insecticide use (MarTins et al. 2009) had detected the allele 1016Ile at the frequency of $73.7 \%$, which was higher than the frequency found in the present work for the same allele (54\%). Our sampling, however, covers a larger area. Nevertheless, the frequency of the 1016Ile allele is high in the results of both studies, which is consistent with the high selective pressure caused by the pyrethroids used in mosquito control.

In our results, the spatial distribution of the genotype that carries the recessive allele is not randomly distributed in the urban area. The analysis of the 1016 mutation frequency should be based on a great number of individuals distributed across a wide geographical area. Consistent with the conclusion of GARCIA et al. (2009), we suggest that, in analyses of the frequency of the 1016 mutation, a large number of individuals over a large area should be used because populations in nearby locations may have very different allele frequencies. According to GARCIA et al. (2009), the frequency of the 1016lle increased from the end of 1990 up to 2006-2009 in several Mexican states. In Nuevo Leon, the 1016Ile mutation was first reported in 1997. In 2003 and 2004 , its frequency had increased by approximately $100 \%$. Spatial heterogeneity was found between two states, and also in smaller geographic scales. Within the city of Chetumal, Quintana Roo, the frequencies of the 1016Ile mutation ranged from $38.3 \%$ to $88.3 \%$. The frequency of the resistant genotype is likely to increase depending on the intensity and the persistence of control actions against the mosquito.

Genotyping the voltage-gated sodium channel gene fragment allows us to predict the effectiveness of pyrethroids. The detection of this mutation in field populations has serious consequences for the sustained use of pyrethroids in mosquito control (Soderlund \& KNIPple 2003, SAavedra-Rodriguez et al. 2007, Donnelly et al. 2009). Certainly, the populations of $A$. aegypti in the field must be continuously monitored to maintain or to restore the susceptibility to pyrethroids, considering that there are few options for chemical control.

With regards to genetic variability, the $\mathrm{H} 1$ haplotype was found at a high frequency, being 100\% similar to haplotype H6 [GenBank: EU650410] found by LiMA-JuNior \& SCARPASSA (2009) in the states of Pará, Acre and the Brazilian Amazon, and haplotype H19 [GenBank: AY906853] found by Paduan \& Ribolla (2008) in the city of Barretos (São Paulo). The H2 haplotype was found less frequently and is $100 \%$ similar to haplotype H10 [GenBank: EU650414] of Lima-Junior \& SCARPassa (2009) in Belém (Pará) and H23 [GenBank: AF334863] of Gorrochotegui-Escalante et al. (2002) in Mexico. The distribution of genetic variants in natural populations is the result of several evolutionary forces and demographic factors (SLATKIN 1985).

Population genetic diversity is expected to be higher when samples collected in large scale are used in haplotype surveys. One example is the work of Bracco et al. (2007), who found high values of genetic diversity $(H d=0.8200$ and $\pi=$ 0.0199) in the analysis of samples from 36 locations in the Americas, Asia and Africa. Conversely, when local surveys are conducted, genetic diversity tends to be lower. The values of genetic diversity ( $H d=0.1310$ and $\pi=0.0047$ ) in our data were low for the ND4 analysis. However, we expected to find more haplotype diversity in Foz do Iguaçu, because of the elevated road traffic and the intense commercial trade with other countries in South America. The low values of genetic diversity in our results may suggest a reduction in the size of the population, which may have suffered a recent bottleneck. Bottlenecks lead to reduced genetic diversity with respect to the original gene pool. In the case of vector populations, bottlenecks are usually associated with control measures, which are more intense when infestation indexes are high and the local populations are being affected by the disease. Genetic polymorphisms may decline rapidly anywhere in the genome of the mosquito due to the use of insecticides (Yan et al. 1998).

We detected four individuals with more than one mitochondrial DNA genotype, a phenomenon called heteroplasmy (Butler \& Levin. 1998). In the same individual, up to five sites with two different nucleotides were observed. A cell can become heteroplasmic following a somatic or germ line point mutation at a specific site or an insertion/deletion mutation (CAlloway et al. 2000). A mechanism that explains the inherited heteroplasmy, and has been observed in Drosophila Fallén, 1823 , is biparental mitochondrial inheritance. In such cases, the father contributes a small number of mtDNA molecules to the progeny (Kondo et al. 1990). Another explanation for the appearance of more than one genotype in the same individual is the sequencing of a nuclear pseudogene within the mito- 
chondrial DNA. Nuclear Mitochondrial pseudogenes, which have been reported for A. aegypti by HLAING et al. (2009) may generate mistakes in the interpretation of heteroplasmy (PARR et al. 2006). However, in the present contribution, we observed that all cases of heteroplasmy occurred in the polymorphic sites, which suggests that parental leakage might have taken place. According to Paduan \& Ribolla (2008), it is possible that parental leakage has been historically underestimated, because sequencing is not the best way to reveal this kind of heteroplasmy in the mitochondrial genome. Almost all of the genetic variation was found within populations $(99.78 \%)$, whereas variation among populations was extremely low $(0.22 \%)$. The value of the fixation index Fst $=0.00217$ was extremely low and the average gene flow $(\mathrm{Nm})$ was high (230) when compared with other studies using A. aegypti. Ayres et al. (2003), using RAPD, found values of $F s t=0.317$ and $\mathrm{Nm}=0.54$ for the Brazilian populations. The values of molecular variance found in our study suggest that populations of $A$. aegypti in the urban area of Foz do Iguaçu are not genetically structured.

According YAN et al. (1998), the assumption that vector populations are in genetic equilibrium can be biased. This is because the interval between the applications of insecticides is usually three to four months, which is much less than the time required for achieving genetic equilibrium in a population. Despite the fact that we divided the urban area of Foz do Iguaçu into strata, we observed that there is a similarity in genetic populations of $A$. aegypti in the urban area as a whole, due to the short geographical distance among the sub-regions analyzed, and the extensive gene flow among them. The high gene flow may explain the rapid spread of the gene responsible for insecticide resistance.

The two mitochondrial strains found by us have the 1016Ile mutation allele, which is homozygous recessive and is associated with resistance. However, genetic variability differs substantially among genes in different regions of the genome (AQUADRo 1992), which means that we need to use different markers to gain a better understanding of the effects selection pressure has on the genetic variability of populations.

Many parameters presented here can change important aspects of the vector competence and capacity of $A$. aegypti. For instance, bottlenecks and/or genetic drift can dramatically change the phenotype of a population with respect to vector competence (Bosio et al. 2005). The individual variation of $A$. aegypti with respect to susceptibility to the dengue virus derives in part from interactions between the genomes of the mosquito and that of the virus, with the potential for infection depending on the specific combination between the genotypes of the vector and the virus (LAMBrechts et al. 2009, 2011). Resistance to pyrethroids can also affect other aspects of vector ability, longevity for example, and the amount of blood that can be ingested, reducing the number and viability of the eggs (Martins et al. 2012). The local dynamics and information about population genetics over time and space should be con- sidered during entomological surveillance of $A$. aegypti, and used in the design of plans to control the vector population.

\section{ACKNOWLEDGEMENTS}

We thank PRONEX - Rede Dengue/CNPq, process \#550116/2010-9; CNPq, process \#305038/2009-5 and \#140231/ 2008-0; Secretaria da Ciência, Tecnologia e Ensino Superior do Estado do Paraná; Rodrigo F. Chitolina for his help; Maria de L. da G. Macoris (SUCEN) for providing data on the pyrethroid biological assays on adults.

\section{LITERATURE CITED}

AquAdro, C.F. 1992. Why is the genome variable? Insights from Drosophila. Trends in Genetics 8 (10): 355-362.

Ayres, C.F.J.; M.A.V. Melo-Santos; A.M. Sole-Cava \& A.F. FurtaDo. 2003. Genetic differentiation of Aedes aegypti (Diptera: Culicidae), the major dengue vector in Brazil. Journal of Medical Entomology 40 (4): 430-435.

Ayres, M.; M. Ayres-Jr; D.L. Ayres \& A.S. Santos. 2007. BioEstat 5.0: Aplicações estatísticas nas áreas das ciências biomédicas. Belém, Sociedade Civil de Mamirauá.

Bosio, C.F.; L.C. Harrington; J.W. Jones; R. Sithiprasasna; D.E. NorRis $\&$ T.W. Scotт. 2005. Genetic structure of Aedes aegypti populations in Thailand using mitochondrial DNA. American Journal of Tropical Medicine and Hygiene 72 (4): 434-442.

Bracco, J.E.; M.L. Capurro; R. Lourenço-De-Oliveira \& M.A.M. SALLUM. 2007. Genetic variability of Aedes aegypti in the Americas using a mitochondrial gene: evidence of multiple introductions. Memórias do Instituto Oswaldo Cruz 102 (5): 573-580.

Braga, I.A.; J.B.P. Lima; S.S. Soares \& D. Valle. 2004. Aedes aegypti resistance to temephos during 2001 in several municipalities in the States of Rio de Janeiro, Sergipe and Alagoas, Brazil. Memórias do Instituto Oswaldo Cruz 99 (2): 199-203.

Braga, I.A. \& D. Valle. 2007a. Aedes aegypti: inseticidas, mecanismos de ação e resistência. Epidemiologia e Serviço de Saúde 16 (4): 279-293.

Braga, I.A. \& D. Valle. 2007b. Aedes aegypti: histórico do controle no Brasil. Epidemiologia e Serviço de Saúde 16 (2): 113-118.

ButLer, J.M. \& B.C. Levin. 1998. Forensic applications of mitochondrial DNA. Tibtech 16 (4): 158-162.

Calloway, C.D.; R.L. Reynolds; G.L. Herrin-Jr \& W.A. WyatT. 2000. The frequency of heteroplasmy in the HVII region of mtDNA differs across tissue types and increases with age. American Journal of Human Genetics 66 (4): 1384-1397.

Costa-Da-Silva, A.L.; M.L. Capurro \& J.E. Bracco. 2005. Genetic lineages in the yellow fever mosquito Aedes (Stegomyia) aegypti (Diptera: Culicidae) from Peru. Memórias do Instituto Oswaldo Cruz 100 (6): 639-644.

Davies, T.G.M.; A.O. O’Reilly; L.M. Field; B.A. Wallace \& M.S. Williamson. 2008. Knockdown resistance to DDT and 
pyrethroids: from target-site mutations to molecular modeling. Pest Management Science 64 (11): 1126-1130.

Donnelly, M.J.; V. Corbel; D. Weetman; C.S. Wilding; M.S. Williamson \& W.C. BLACK. 2009. Does kdr genotype predict insecticide-resistance phenotype in mosquitoes? Trends Parasitology 25 (5): 213-219.

Duque, L.J.E; R.V. Da Silva; E.F. Kuwabara \& M.A. Navarro-Silva. 2010. Dengue no Estado do Paraná, Brasil: distribuição temporal e espacial no período 1995-2007. Salud UIS 42 (2): 113-122.

EXCOFfIER, L. \& H.E.L. Lischer. 2010. Arlequin suite ver 3.5: A new series of programs to perform population genetics analyses under Linux and Windows. Molecular Ecology Research 10 (3): 564-567.

FaY, R.W. \& D.A. ELIASON.1966. A preferred oviposition sites as surveillance methods for Aedes aegypti. Mosquito News 26: 531-535.

Finney, D.J.1971. Probit Analysis. Cambridge, University Press, $3^{\text {rd }}$ ed.

García, G.P.; A.E. Flores; I. Fernández-Salas; K. Saavedra-Rodríguez; G. Reyes-Solis; S. Lozano-Fuentes; J.G. Bond; M. Casas-Martínez; J.M. Ramsey; J. García-Rejón; M. Domínguez- Galera; H. Ranson; J. HemingwaY; L. Eisen \& W.C. Black. 2009. Recent Rapid Rise of a Permethrin Knock Down Resistance Allele in Aedes aegypti in México. PLoS Neglected Tropical Diseases 3 (10): 531-541.

Gorrochotegui-Escalante, N.; C. Gómez-Machorro; S. Lozano-Fuentes; I. Fernandez-Salas; M.L. Munoz; J.A. Farfan-Ale; J. Garcia-Rejon; B.J. BEATY \& W.C. BLACK Iv. 2002. Breeding structure of Aedes aegypti populations in México varies by region. American Journal of Tropical Medicine and Hygiene 66 (2): 213-222.

Guirado, M.M. \& H.E.M.C. Bicuso. 2009. Alguns aspectos do controle populacional e da resistência a inseticidas em Aedes aegypti (Diptera, Culicidae). Boletim Epidemiológico Paulista 6 (64): 5-14.

Gütler, R.E.; F.M. Garelli \& H.D. Coto. 2009. Effects of a fiveyear citywide intervention program to control Aedes aegypti and prevent dengue outbreaks in northern argentina. PLOS Neglected Tropical Diseases 3 (4): e427.

HALL, T. 2004. Bioedit version 7.0.0. Ibis Therapeutics Carlsbad, CA.

Harthl, D.L. 2008. Princípios de genética de populações. Ribeirão Preto, FUNPEC, $3^{\text {rd }}$ ed.

Hemme, R.R.; C.L. Thomas; D.D. Chadee \& D.W. Severson.2010. Influence of urban landscapes on population dynamics in a short- distance migrant mosquito: Evidence for the dengue vector Aedes aegypti. PLoS Neglected Tropical Diseases 4 (3): 634-643.

Hiragi, C.; K. Simões; E. Martins; P. Queiroz; L. Lima \& R. Monnerat. 2009. Variabilidade Genética em Populações de Aedes aegypti (L.) (Diptera: Culicidae) Utilizando Marcadores de RAPD. Neotropical Entomology 38 (4): 542-547.

Hlaing, T.; W. Tun-Lin; P. Somboon; D. Socheat; T. Setha; C. Min Sein; M. Seng \& W. Catherine. 2009. Mitochondrial pseudo- genes in the nuclear genome of Aedes aegypti mosquitoes: implications for past and future population genetic studies. BMC Genetics 10 (11): 1-12.

Івяе. 2011. Instituto Brasileiro de Geografia e Estatística. Available online at: http://www.ibge.gov.br/cidadesat/ topwindow.htm?1 > [Accessed: XI/2011]

Julio, N.B.; M.B. Chiappero; H.J. Rossi; J.C.R. Dueñas \& C.N. GARDENAL. 2009. Genetic structure of Aedes aegypti in the city of Córdoba (Argentina), a recently reinfested área. Memórias do Instituto Oswaldo Cruz 104 (4): 626-631.

Kawada, H.; Y. Higa; O. Koma Gata; S. Kasai; T. Tomita; N. Thi Yen; L.L. LOAN; R.A.P. SÁNChEz \& M. TAKAgI. 2009. Widespread Distribution of a newly found point mutation in voltage-gate d sodium channel in pyrethroid-resistant Aedes aegypti populat ions in Vietnam. PLoS Neglected Tropical Diseases 3 (10): e527.

KIMURA, M. 1968. Evolutionary rate at the molecular level. Nature 217: 624-626.

Kondo, R.; Y. Satta; E.T. Matsuura; H. Ishiwa; N. Takahatat \& S.I.Chigusa. 1990. Incomplete maternal transmission of mitochondrial DNA in Drosophila. Genetics 126 (3): 657-663.

Lambrechts, L.; C. Chevillon; R.G. Albright; B. Thaisomboonsuk; J.H. Richardson; R.G. Jarman \& T.W. Scott. 2009. Genetic specificity and potential for local adaptation between dengue viruses and mosquito vectors. BMC Evolutionary Biology 9: 160-171.

LAMBRECHTS, L. 2011. Quantitative genetics of Aedes aegypti vector competence for dengue viruses: towards a new paradigm? Trends Parasitology 27 (3): 111-114.

Librado, P.\& J. Rozas. 2009. DnaSP v5: A software for comprehensive analysis of DNA polymorphism data. Bioinformatics 25 (11):1451-1452.

Lima, J.B.P.; M. Pereira Da Cunha; R.C.S. Silva-Jr; A.K.R. Galardo; S.S. Soares; I.A. Braga; R.P. Ramos \& D. Valle. 2003. Resistance of Aedes aegypti to organophosphates in several municipalities in State of Rio de Janeiro and Espírito Santo, Brasil. American Journal of Tropical Medicine and Hygiene 68 (3): 329-333.

Lima, E.P.; M.H.S. Paiva; A.P. Araújo; E.V.G. Silva; U.M. Silva; L.N. Oliveira; A.E.G. Santana; C.N. Barbosa; C.C.P. Neto; M.O.F. Goulart; C.S. Wilding; C.F.J. Ayres \& M.A.V.M. SAntos. 2011. Insecticide resistance in Aedes aegypti populations from Ceará, Brazil. Parasitology Vectors 4: 5.

Lima-JúnIOR, R.S. \& V.M. SCARPassa. 2009. Evidence of two lineages of the dengue vector Aedes aegypti in the Brazilian Amazon, based on mitochondrial DNA ND4 gene sequences. Genetics and Molecular Biology 32 (2): 414-422.

Llinas, G A.; E. Seccacini; C.N. Gardenal \& S. Licastro. 2010. Current resistance status to temephos in Aedes aegypti from different regions of Argentina. Memórias do Instituto Oswaldo Cruz 105 (1): 113-116.

Macoris, M.L.G.; M.F. Camargo; I.G. Silva; L. Takaku \& M.T. AndrighetTi. 1995. Modificação da susceptibilidade de Aedes (Stegomyia) aegypti ao temephos. Revista de Patologia Tropical 24: 31-40. 
Macoris, M.L.D.; M.T. AndrighetTi; L. TAKaku; C.M. Glasser; V.C. Carbeloto \& J.E. Bracco. 2003. Resistance of Aedes aegypti from the State of São Paulo, Brazil, to organophosphates Insecticides. Memórias do Instituto Oswaldo Cruz 98 (5): 703-708.

Martins, A.J.; J.B.P. Lima; A.A. Peixoto \& D. Valle. 2009. Frequency of Val1016Ile mutations in the voltage-gated sodium channel gene of Aedes aegypti Brazilian populations. Tropical Medicine \& International Health 14 (11): 1351-1355.

Martins, A.J.; C.D.M. Ribeiro; D.F. Bellinato; A.A. Peixoto; D. Valle \& J.B.P. Lima. 2012. Effect of insecticide resistance on development, longevity and reproduction of field or laboratory selected Aedes aegypti populations. Plos One 7 (3): e31889.

MazzARI, M.B. \& G.P. Georghio. 1995. Characterization of resistance to organophosphate, carbamate, and pyrethroid insecticides in field populations of Aedes aegypti from Venezuela. American Mosquito Control Association 11 (3): 315-322.

MinISTÉRIO DA SAÚdE. 2005. Diagnóstico rápido nos municípios para vigilância entomológica do Aedes aegypti no Brasil - LIRAa. Metodologia para avaliação dos índices do Breteau e Predial. Brasília, Ministério da Saúde.

MinISTÉRIO DA SAÚdE. 2006. Secretaria de Vigilância em Saúde, Coordenação Geral do Programa Nacional de Controle da Dengue. Reunião técnica para discutir status de resistência de Aedes aegypti a inseticidas. Brasília, Ministério da Saúde.

Montella, I.R.; A.J. Martins; P.F. Viana-Medeiros; J.B.P. Lima; I.A. Braga \& D.Valle. 2007. Insecticide Resistance Mechanisms of Brazilian Aedes aegypti Populations from 2001 to 2004. American Journal of Tropical Medicine and Hygiene 77 (3): 467-477.

Paduan, K.S. \& P.E.M. Ribolla. 2008. Mitochondrial DNA polymorphism and heteroplasmy in populations of Aedes aegypti in Brazil. Journal Medical Entomology 45 (1): 59-67.

Paupy, C.; C. Brengues; O. Ndiathc; C. Totyb; J.P. Hervéb \& F. Simard. 2010. Morphological and genetic variability within Aedes aegypti in Niakhar, Senegal. Infection, Genetics and Evolution 10 (4): 473-480.

Parr, R. L.; J. Maki; B. Reguly; G. D. Dakubo; A. Aguirre; R. Wittock; K. Robinson; J.P. Jakupciak \& R.E. Thayer. 2006. The pseudomitochondrial genome inûuences mistakesin heteroplasmy interpretation. BMC Genomics 7: 185

Pereira-Da-Cunha, M.; J.B.P. Lima; W.G. Brogdon; G.E. Moya \& D. VALLE. 2005. Monitoring of resistance to the pyrethroid cypermethrin in Brazilian Aedes aegypti (Diptera:Culicidae) populations collected between 2001 and 2003. Memórias do Instituto Oswaldo Cruz 100 (4): 441-444.

Prophiro, J.S.; O.S. Silva; J.E.D. Luna; C.F. Piccoli; L.A. Kanis \& M.A. Navarro-Silva. 2011. Aedes aegypti and Aedes albopictus
(Diptera: Culicidae): coexistence and susceptibility to temephos, in municipalities with occurrence of dengue and differentiated characteristics of urbanization. Revista da Sociedade Brasileira de Medicina Tropical 44 (3): 300-305.

SaAvedra-Rodriguez, K.; L. Urdaneta-Marquez; S. Rajatileka; M. Moulton; A.E. Flores; I. Fernandez-Salas; J. Bisset; M. Rodriguez; P.J. Mccall; M.J. Donnelly; H. Ranson; J. Hemingway \& W.C. BLACK. 2007. A mutation in the voltage-gated sodium channel gene associated with pyrethroid resistance in Latin American Aedes aegypti. Insect Molecular Biology 16 (6): 785-798.

SALMAN, A.K.D. 2007. Conceitos básicos de genética de populações. Porto Velho, Embrapa, Documentos 118.

Seccacini, E; A. Lucia; E. Zerba; S. Licastro \& E. Masuh. 2008. Aedes aegypti resistance to temephos in Argentina. American Mosquito Control Association 24: 608-609.

Slatkin, M. 1985. Gene flow in natural populations. Annual Review of Ecology and Systematics 16: 393-430.

Soderlund, D.M. \& D.C. KNIPple. 2003. The molecular biology of knockdown resistance to pyrethroid Insecticides. Insect Biochemistry and Molecular Biology 33 (6): 563-577.

TAuil, P.L. 2001. Urbanização e ecologia do dengue. Cadernos de Saúde Pública 17: 99-102.

Thompson, J.D.; D.G. Higgins; T.J. Gibson. 1994. Clustal W: improving the sensitivity of progressive multiple sequence alignment through sequence weighting, position-specific gap penalties and weight matrix choice. Nucleic Acids Research 22 (22): 4673-4680.

WHO. 1981a. Instructions for determining the susceptibility resistance of mosquito larvae to insecticides. Geneva, World Health Organization, VBC, 81.807.

WHO. 1981b. Criteria and Meaning of Tests for Determining the susceptibility or Resistance of Insects to insecticides. Geneva, World Health Organization, VBC, 81.806.

Wно. 1981C. Instructions for determining the suscetibility or resistance of adult mosquitoes to organochlorine, organophosphate and carbamate insecticides. Stablishment of the baseline. Geneva, World Health Organization, VBC, 81.805 .

WHO. 1992. Vector resistance to pesticides. Geneva, World Health Organization, Technical Report Series \#818.

WHO. 1998. Test procedures for insecticide resistance monitoring in malaria vectors, bio efficacy and persistence of insecticides on treated surfaces. Geneva, World Health Organization, CDS/CPC/MAL, 98.12.

Yan, G.; D.D. ChadeE \& D.W. Severson. 1998. Evidence for genetic hitchhiking effect associated with insecticide resistance in Aedes aegypti. Genetics 148 (2): 793-800.

ZAR, J.H. 2010. Biostatistical analysis. Upper Saddle River, N.J.: Prentice-Hall, $5^{\text {th }}$ ed.

Submitted: 27.VII.2012; Accepted: 14.XI.2012.

Editorial responsibility: Walter A.P. Boeger

ZOOLOGIA 29 (6): 540-548, December, 2012 